\title{
FUNCTIONAL HEALTH ASSESSMENT AS THE DETERMINANT OF SOCIAL CARE MANAGEMENT
}

\author{
Agnieszka Bem \\ Wroclaw University of Economics, Poland \\ E-mail: agnieszka.bem@ue.wroc.pl \\ Paulina Ucieklak-Jeż \\ Jan Dlugosz University in Czestochowa, Poland \\ E-mail: p.ucieklak-jez@ajd.czest.pl
}

\begin{abstract}
The aim of this study is to assess the functional state of health for elderly residents in Poland. The analysis has been using the data from the survey "Social Diagnosis" carried out in 2013, in Poland. The research concentrates on subjective measures, used to assess the population's state of health, based both on mortality and disability studies, while disability is defined as reduced ability to carry out daily activities. The authors have evaluated the health status of the elderly in Poland in 2013, using measures of health function (ADL) and activity restrictions (IADL). The results show, that functional health of older people in Poland is significantly correlated with age and sex of respondents. The interpretation and the conceptualization of desirable directions of changes should lead to active life style's promoting, adjusted, accordingly, to health state and age. It also provides important information for social care managers, by defining needed form of interventions.
\end{abstract}

Key words: healthy aging, social care management, Life expectancy without self-care activity restrictions (ADL), Life expectancy without instrumental activity restrictions (IADL).

\section{Introduction}

Demographic ageing of the population, reflected in an increase in the percentage of old people in society, is one of the social processes that focus the attention of researchers of many disciplines, including economists. The aging population creates new problems for health care, social welfare and pension systems. Higher strength of older people increases the demand for health services and nursing care. Hence, from the point of view of social welfare, it is important to support the longest possible period of independent existence, especially in the home environment. The planning of social welfare benefits, however, requires tools enabling evaluation of ability to carry out daily activities.

The study on older people population health: "Survey of Health Ageing and Retirement in Europe (SHARE)" is one of the first surveys, the aim of which is to assess population's health state. SHARE research questionnaire contains a question concerning health status perception. The study is carried out in the framework of the EU program - Public Health Program (PHP) as a part of the project entitled European Health Expectancy Monitoring Unit (EHEMU). The aim of this project is to improve a construction of population's health measures, further development of their quality, indicating inequalities in health in European countries and supporting construction of the European health monitoring system.

In the year 2000, in Poland, under the leadership of Prof. J. Czapiński, a project called "Social Diagnosis" was launched. This project is based on assessment of institutional indicators, using comprehensive data on households, a health status and quality of life. In 2013, on 
Agnieszka BEM, Paulina UCIEKLAK-JEŻ. Functional Health Assessment as the Determinant of Social Care Management

PROBLEMS

OF MANAGEMENT

IN THE $21^{\text {st }}$ CENTURY Vol. 9, No. 3, 2014

198

the basis of "Social Diagnosis" a thematic report entitled "Social Activity of the Elderly in the Context of the Perception of the Poles" was created. The results of "Social Diagnosis" picture a state of Polish society. The data, collected within the framework of the project, allow the calculation of socio-medical measures, in order to evaluate and improve the state of health in Poland.

The phenomenon of ageing implies the prevalence of chronic diseases and disabilities and, as a result of above, high dependency needs (Mossakowska, 2012). Disability is usually defined in terms of limitations of the ability to perform daily living activities or inability to function in the basic or instrumental sense (WHO, 2003; Chappell, 2010). International Classification of Functioning, Disability and Health (ICF) (WHO, 2001; Chappell, 2010) defines disability as "a result of complex relationships between an individual's health condition and personal factors, and of the external factors that represent the circumstances in which the individual lives". Disability is conceptualized in terms of negative dimensions of individual - environment relation - deficits and activity restrictions. For seniors, disability means limitations related to daily activities, or those, which allow independent living (Millan-Calenti et all., 2010). According to this, health can be described as the ability to carry out daily activities at home and, also, in society (Fange, 2009).

Independence is a key word related to the ageing process. Dependence is an important problem, because of an impact on the elderly's quality of life and mortality (Garatachea, 2009). Many older people wish to live independently, in their own homes, as long as possible (Gitlin, 2003; Dujardin, 2014). Seniors, especially the oldest ones, spend every important part of life in their own home (in case of very old people even $80 \%$ ) or its close surroundings. "Aging-inplace" builds up independence, well-being and social participation of the elderly (Fange, 2009; Sixsmith, 2014).

Mobility and self-reliance ability are the key factors, that allow senior members of society to stay independent even in late old age (Stjernborg, Melin, Ståhl, 2014). However, for the elderly with disabilities, successful aging in their own home may be jeopardized by physical barriers in residential environment.

The starting point for constructing socio-medical measures, used for the health assessment was the concept of "limited social skills", understood as the inability to perform tasks (activities of daily living) accordingly to the age and gender.

Daily activities are divided into two categories: basic and instrumental ones. The scale of basic daily living activities' assessment (Activities of Daily Living - ADL) refers to selfservice-related tasks - personal care - such as 'eating', 'transferring from bed to chair', 'doing personal toilet', 'toilet use', 'taking a bath or a shower', 'walking on a corridor', 'ascend and descend stairs', 'dressing', 'bowel continence', 'urine continence') etc. Instrumental daily living activity assessment (Instrumental Activities of daily Living - IADL) refers to those activities, that are necessary to stay in the home environment (household management), like: ('ability to use telephone', 'shopping', 'food preparation', 'housekeeping', 'laundry', 'travelling via car or public transportation', 'medication use', 'ability to handle finances'(Ramos-Pichardoiinni, 2014), (Roehrig, 2007). Usually, ADL and IADL functions are analyzed separately (Kempen, Myers, Powell, 1995).

ADL relates to activities essential for an independent life. IADL requires a higher level of autonomy (making decisions) and, as a result, more intensive interaction with the environment. That's why deficits in IADL usually appear earlier (Millan-Calenti et all., 2010). Both ADL and IADL deficits impact quality of life, but ADL, especially at very high age, influence negatively on mental well-being (Werngren-Elgstrom, Carlsson, Iwarsson, 2009). Deficit type is crucial to make decisions concerning a form of social intervention (home care or nursing home) (Finlayson, Mallinson, Barbosa, 2005).

It is worth nothing, that senior, getting the same scores in ADL or IADL test can represent quite opposite patterns of disability, and it, generally, depends on the stage of limitations (Stineman, 2014). 
The aim of this study is to assess the life expectancy without limitations in daily functioning, using the ADL and IADL. A comparison of these expectancies with total life expectancy (LE) allows the assessment of needs related to the provision of social services.

The authors have adopted the major research assumption: demographic changes make it necessary to improve the physical activity of older people. In the course of work, two research hypotheses have been created:

Hypothesis H1: gender is one of the most important factors, determining the functional state of health of the elderly;

Hypothesis H2: occurring of health problems, limiting performance of daily activities or participating in other activities, is significantly correlated with the age of respondents.

The data come from the survey, presented in the thematic report "Social Activity of the Elderly in the Context of the Perception of the Poles" published in 2014 in Poland.

\section{Methodology of Research}

In this study, the social and medical indicators have been used. Those indicators are based on functional performance criteria and the social activity, so these are measures of the impact of health and disease on performing social roles. These measures are divided into two groups - measures of health self-assessment, and measures of function restrictions (Table 1).

Table 1. The measures of health self-assessment and function restrictions.

\begin{tabular}{ll}
\hline Life Expectancy & \\
\hline Health self-assessment & Functional health \\
Healthy Life Expectancy - HLE & Life Expectancy without Self-care Activity Restrictions - ADL \\
& Life Expectancy without Instrumental Activity Restrictions - IADL \\
\hline
\end{tabular}

Source: own study based on (Robine, Jagger, 2006).

A measure, that allows health self-assessment of the elderly population is Healthy Life Expectancy - HLE (Ucieklak-Jeż, 2012). While functional performance measures indicate the degree of disability of the elderly, their independence from the environment to meet basic needs or depending on other people, and are used to assess the degree of various difficulties, related to the state of health, which cause physical restrictions of the elderly.

Measures, which specify the functional efficiency are: Life Expectancy without Self care Activity Restrictions - ADL and Life Expectancy without Instrumental Activity Restrictions - IADL. Assessing functional and activity restrictions in surveys, is difficult. Historically, many surveys on ageing, attempted to elicit information on activity restriction by the self-report of an individual's need for help in performing basic personal care activities (bathing, dressing, using the toilet), known as Activities of Daily Living (ADLs) (Katz, 1963) or by household activities (shopping, cooking, doing the laundry), known as Instrumental Activities of Daily Living (IADLs) (Lawton, 1969).

The main source of data, used to calculate ADL and IADL measures for Polish population, are:

- Life tables, compiled by the Central Statistical Office of Poland (GUS, 2014);

- The data from the survey "Social Diagnosis", carried out in 2013 (Czapiński, 2014).

Construction of life table is based on the probabilities of death:

$$
q_{x}=1-\left(1-q_{1 x}\right)\left(1-q_{2 x}\right) \text { for } 0 \leq x \leq 84,
$$

where: 
PROBLEMS

OF MANAGEMENT

IN THE $21^{\text {st }}$ CENTURY Vol. 9, No. 3, 2014

200

$P_{x}(t)$ - the number of persons aged $\mathrm{x}$ at the end of year $\mathrm{t} ; D_{1 x}(t)$ - the number of death in year $t$ at the age of $x$, amongst people born in year $t-x-1 ; D_{2 x}(t)$ - the number of persons deceased in year $t$ at the age of $\mathrm{x}$ amongst people born in year $t-x ; K_{x}(t)$-correction for the number of population in year $t$ with regard to migration of persons born in year $t$ - $x$ (GUS, 2014).

Probabilities of death are calculated up to the age of 84 years old (inclusively), applying the formulas presented above. During the next stage of the calculation, the results are extrapolated for population over 84 years, and compensated at the age from 1 to 84 years. The exact procedure of life tables estimations is presented in the literature (Ucieklak-Jeż, 2012).

Basing on the average value of further lifespan, using the Sullivan method, the following measure: Life Expectancy without Self-care Activity Restrictions - ADL and Life Expectancy without Instrumental Activity Restrictions - IADL, have been estimated.

\section{Results of Research}

The results of the estimated average life expectancy without basic restrictions on independent self-care of women and men in old age are shown in tables 2 and 3.

Table 2. Estimation of life expectancy without basic restrictions (ADL) for men.

\begin{tabular}{llllllll}
\hline Age & Probability of death & Life expectancy & $\begin{array}{l}\text { Proportion of age } \\
\text { group with disability }\end{array}$ & $\begin{array}{l}\text { Life expectancy } \\
\text { without self-care } \\
\text { activity restric- } \\
\text { tions }\end{array}$ & $\% A D L_{M} / e_{x}$ \\
\hline$x, x+n$ & $q_{x}$ & $S\left(q_{x}\right)$ & $e_{x}$ & $S\left(e_{x}\right)$ & $\pi_{x}$ & $A D L_{M}$ & $A D L, \%$ \\
\hline $60-64$ & 0.09866 & 0.00059 & 18.73 & 0.02 & 0.147 & 14.61 & 78.03 \\
\hline $65-69$ & 0.13583 & 0.00085 & 15.50 & 0.02 & 0.209 & 11.72 & 75.59 \\
\hline $70-74$ & 0.18703 & 0.00116 & 12.53 & 0.02 & 0.195 & 9.29 & 74.16 \\
\hline $75-79$ & 0.26838 & 0.00142 & 9.82 & 0.02 & 0.258 & 6.94 & 70.69 \\
\hline $80-84$ & 0.38363 & 0.00183 & 7.48 & 0.02 & 0.324 & 5.10 & 68.15 \\
\hline $85-+$ & 1.00000 & 0.00000 & 5.60 & 0.01 & 0.324 & 3.84 & 68.54 \\
\hline
\end{tabular}

Life expectancy without basic restrictions for men is reduced in subsequent age groups, which is naturally associated with lowering total life expectancy. It is Important, however, that in subsequent age groups the relationship of ADL to LE is reduced (Table 2). 
Table 3. Estimation of life expectancy without basic restrictions (ADL) for wom-

en.

\begin{tabular}{llllllll}
\hline Age & Probability of death & Life expectancy & $\begin{array}{l}\text { Proportion } \\
\text { of age group } \\
\text { with disability }\end{array}$ & $\begin{array}{l}\text { Life expectancy } \\
\text { without self-care } \\
\text { activity restrictions }\end{array}$ & $\% A D L_{K} / e_{x} \%$ \\
\cline { 1 - 6 }$x, x+n$ & $q_{2 x}$ & $S\left(q_{2 x}\right)$ & $e_{2 x}$ & $S\left({ }_{e 2 x}\right)$ & $\pi_{2 x}$ & $A L_{k}$ & \\
\hline $60-64$ & 0.04259 & 0.00038 & 23.86 & 0.02 & 0.183 & 15.89 & 66.61 \\
\hline $65-69$ & 0.06213 & 0.00055 & 19.80 & 0.02 & 0.234 & 12.42 & 62.75 \\
\hline $70-74$ & 0.09286 & 0.00073 & 15.94 & 0.02 & 0.331 & 9.29 & 58.29 \\
\hline $75-79$ & 0.15785 & 0.00093 & 12.30 & 0.01 & 0.368 & 6.73 & 54.68 \\
\hline $80-84$ & 0.27472 & 0.00122 & 9.10 & 0.01 & 0.509 & 4.53 & 50.78 \\
\hline $85-+$ & 1.00000 & 0.00000 & 6.55 & 0.01 & 0.509 & 3.33 & \\
\hline
\end{tabular}

ADL analysis for women has shown, that life expectancy without basic restrictions declines faster than for men. Taking into consideration longer women's life expectancy (LE), the relationship of ADL to LE is definitely less favourable (Table 3).

The results of estimated average lifespan without instrumental restrictions for women and men in old age are presented in tables 4 and 5 .

Table 4. Estimation of life expectancy without instrumental restrictions (IADL) for men.

\begin{tabular}{llllllll}
\hline Age & Probability of dying & Life expectancy & $\begin{array}{l}\text { Proportion of } \\
\text { age group with } \\
\text { disability }\end{array}$ & $\begin{array}{l}\text { Life expectancy } \\
\text { without self-care } \\
\text { activity restric- } \\
\text { tions }\end{array}$ & IADL $L_{2 M} / e_{x} \%$ \\
\cline { 1 - 7 }$x \cdot x+n$ & $\mathrm{q}_{x}$ & $\mathrm{~S}\left(\mathrm{q}_{x}\right)$ & $\mathrm{e}_{x}$ & $\mathrm{~S}\left(\mathrm{e}_{x}\right)$ & $\pi_{x}$ & $\mathrm{IADL}_{M}$ & \\
\hline $60-64$ & 0.09866 & 0.00059 & 18.73 & 0.02 & 0.207 & 12.53 & 66.90 \\
\hline $65-69$ & 0.13583 & 0.00085 & 15.50 & 0.02 & 0.265 & 9.72 & 62.71 \\
\hline $70-74$ & 0.18703 & 0.00116 & 12.53 & 0.02 & 0.287 & 7.28 & 58.14 \\
\hline $75-79$ & 0.26838 & 0.00142 & 9.82 & 0.02 & 0.307 & 4.99 & 50.76 \\
\hline $80-84$ & 0.38363 & 0.00183 & 7.48 & 0.02 & 0.397 & 2.71 & 36.27 \\
\hline $85-+$ & 1.00000 & 0.00000 & 5.60 & 0.01 & 0.397 & 0.45 & 8.01 \\
\hline
\end{tabular}

Life expectancy without instrumental restriction (IADL) for men is lower than ADL, which results in a lower participation of functioning without limitation (IADL), in total life expectancy (LE). Especially important is the strong reduction of IADL in the oldest age group $(85+)$ (Table 4). 
PROBLEMS

OF MANAGEMENT IN THE $21^{\text {st }}$ CENTURY Vol. 9, No. 3, 2014

202

Table 5. Estimation of life expectancy without instrumental restrictions (IADL) for women.

\begin{tabular}{llllllll}
\hline Age & Probability of dying & Life expectancy & $\begin{array}{l}\text { Proportion of } \\
\text { age group with } \\
\text { disability }\end{array}$ & $\begin{array}{l}\text { Life expectancy } \\
\text { without self-care } \\
\text { activity restric- } \\
\text { tions }\end{array}$ & $I A D L_{2 K} / e_{x} \%$ \\
\cline { 1 - 7 }$x \cdot x+n$ & $\mathrm{q}_{2 x}$ & $\mathrm{~S}\left(\mathrm{q}_{2 x}\right)$ & $\mathrm{e}_{2 x}$ & $\mathrm{~S}\left(\mathrm{e}_{x}\right)$ & $\pi_{2 x}$ & $\mathrm{IADL}_{2 K}$ & \\
\hline $60-64$ & 0.04259 & 0.00038 & 23.86 & 0.02 & 0.236 & 15.10 & 63.29 \\
\hline $65-69$ & 0.06213 & 0.00055 & 19.80 & 0.02 & 0.306 & 11.87 & 59.94 \\
\hline $70-74$ & 0.09286 & 0.00073 & 15.94 & 0.02 & 0.392 & 9.07 & 56.89 \\
\hline $75-79$ & 0.15785 & 0.00093 & 12.30 & 0.01 & 0.450 & 9.07 & 55.30 \\
\hline $80-84$ & 0.27472 & 0.00122 & 9.10 & 0.01 & 0.547 & 5.07 & 55.70 \\
\hline $85-+$ & 1.00000 & 0.00000 & 6.55 & 0.01 & 0.366 & 4.2 & 65.57 \\
\hline
\end{tabular}

IADL analysis for women has given very interesting results. IADL value, in relation to the LE for women does not fall as quickly as for men and for women aged over 75 years is higher (both in absolute values and in relation to LE) than for men in respective age groups. This difference is particularly evident in the age group $85+$ (Table 5).

The analysis indicates, that there is an important difference in the participation (\%) of the average lifespan without restrictions (independently of the type) in life expectancy (Ex) for women and men.

The hypothesis $\mathrm{H} 1$ assumed, that sex might be one of the most important factors, determining the functional state of health of the elderly. The analysis, carried out using the Sullivan's method, has allowed the estimation of ADL and IADL measures, what has partially confirmed the hypothesis H1. It has turned out, that women aged 60 years, in 2013, are to live, on average, almost 16 years without basic restrictions on independent self-care, and males - on average, 15 years. It is important, that ADL for women constitutes $66.61 \%$, and ADL for men $-78.03 \%$ of their life expectancy. Men live shorter, but their functional state of health is better, than the functional state of elderly women. Men, in every age group, report better state of functional health.

Women, aged 60, can expect, on average, 15 years of life without instrumental activity restrictions, and males, on average, 13 years. IADL for women represents $63.29 \%$ and men $66.90 \%$ of their life expectancy. That indicates the existence of the pattern, analogous to the ADL measure.

What's the most important, the ADL and IADL measures, regardless of gender, decrease with age and significantly correlate with the age of respondents. That allows the positive verification of the hypothesis $\mathrm{H} 2$.

\section{Discussion}

Research on the functional limitations of older people are usually limited to an assessment of the patient's current state. Those studies usually show a significant association between age, gender and dependence (Millán-Calenti et all., 2010), (Spector, Katz, Murphy, \& Fulton, 1987), (Brown, 2014), especially for the age group 85+ (Wilms, Riedel-Heller, \& Angermeyer, 2007), (Finlayson, Mallinson, Barbosa, 2005), resulting in higher needs for care. While studies on stability across time in the prevalence of ADL show mixed results, only a few studies proved gender differences - generally women have a higher ADL disability than men (Sjolund, 2014).

However, lack of information concerning life expectancy in the populations, does not allow for a direct comparison of results. Only a few studies relate directly to the life expectancy of the ADL and IADL. 
It should be also noticed, that after the analysis of the measures, a clear division into, at least, two groups of older people has occurred - groups of, so-called, III and IV age. The first group (III age), includes respondents aged 65-79 is characterized by relatively high physical fitness, self-care abilities and performing of daily activities in the household. In the second group, aged 80+ (IV age) some reduction in the level of abilities can be observed more often, the dependence on other people rises, as well as the deteriorating state of health. These persons, characterized as "very old", are especially exposed to health problems, which may strongly limit their functional disability and dependence. Studies suggest, that some social programs, like preventive home visit or senior meetings, might postpone the loss of independency (Behm et all., 2014).

\section{Conclusions}

According to present study it can be concluded, that health is only one of many factors, affecting the seniors' well-being. The sense of general well-being is determined not only by the physical and mental state of health, but also by living conditions, circumstances and functioning in society, what, in practice, defines the ability to live independently, with a sense of independence from the others.

Estimations of ADL and IADL measures, carried out during this study, have partly confirmed research hypotheses. According to them, sex and age are the important factors, which determine the functional state of health of the elderly.

The results show, that the ability to an independent existence deteriorates with age, however, the pattern of changes is strongly associated with sex. For men the ability to live without basic restrictions, measured by ADL, slowly decreases, for women, the development of instrumental restrictions, measured by IADL, is slower. These differences are most visible in the oldest group of people $(85+)$. The existence of differences between sexes indicates the need for further research of factors, affecting life expectancy without restrictions.

Mixed results of disability studies indicate the necessity for more complex research, mainly because of the strong influence on the organization of social care for the elderly. The assessment of the presented measures provides essential information, which allows to plan social intervention. It it especially important in the context of development of "aging-at-place" policy.

\section{References}

Behm, L., Wilhelmson, K., Falk, K., Eklund, K., Ziden, L., Dahlin-Ivanoff, S. (2014). Positive health outcomes following health-promoting and disease-preventive interventions for independent very old persons: Long-term results of the three-armed RCT Elderly Persons in the Risk Zone. Archives of Gerontology and Geriatrics, 58, 376-383.

Brown, J. K., Kurichi, J. E., Xie, D., Pan, Q., Stineman, M. G. (2014). Instrumental activities of daily living staging as a possible clinical tool for falls risk assessment in physical medicine and rehabilitation. $P M$ and $R, 6$ (4), 316-323.

Chappell, N. L., Cooke, H. A. (2010). Age Related Disabilities - Aging and Quality of Life. International Encyclopedia of Rehabilitation. Retrieved 15/08/2014, from http://cirrie.buffalo.edu/encyclope$\mathrm{dia} / \mathrm{en} /$ article/189/.

Czapiński, J., Błędowski, P. (2014). Aktywność społeczna osób starszych w kontekście percepcji Polaków. Retrieved 15/08/2014, from http://www.diagnoza.com/pliki/raporty_tematyczne/Aktywnosc_spoleczna_osob_starszych.pdf.

Dujardin, C., Lorant, V., Thomas, I. (2014). Self-assessed health of elderly people in Brussels: Does the built environment matter? Health \& Place, 27, 59-67.

Fange, A., Dahlin Ivanoff, S. (2009). The home is the hub of health in very old age: Findings from the ENABLE-AGE Project. Archives of Gerontology and Geriatrics, 48, 340-345.

Finlayson, M., Mallinson, T., Barbosa, V. M. (2005). Activities of daily living (ADL) and instrumental activities of daily living (IADL) items were stable over time in a longitudinal study on aging. Journal of Clinical Epidemiology, 58, 338-349. 
Agnieszka BEM, Paulina UCIEKLAK-JEŻ. Functional Health Assessment as the Determinant of Social Care Management

PROBLEMS

OF MANAGEMENT

IN THE $21^{\text {st }}$ CENTURY Vol. 9, No. 3, 2014

204

Garatachea, N., Molinero, O., Martınez-Garcıa, R., Jimenez-Jimenez, R., Gonzalez-Gallego, J., \& Marquez, S. (2009). Feelings of well being in elderly people: Relationship to physical activity and physical function. Archives of Gerontology and Geriatrics, 48, 306-312.

Główny Urząd Statystyczny (2014). Trwanie życia w 2013r. - Warszawa: GUS.

Gitlin, L. N. (2003). Conducting research on home environments: Lessons learned and new directions. The Gerontologist, 43 (5), 628-637.

Katz, S., Ford, A. B., Moskowitz, R. W., Jackson, B. A., Jaffe, M. W. (1963). Activities of Daily Living (ADL). Journal of the American Medical Association, 185, 914-923.

Kempen, G., Myers, A., Powell, M. (1995). Hierarchical Structure in ADL and IADL: Analytical Assumption and Application Clinicians and Researchers. Journal of Clinical Epidemiology, 11, 1299-1305.

Millan-Calenti, J. C., Tubı, J., Pita-Fernandez, S., Gonzalez-Abraldes, I., Lorenzo, T., Fernandez-Arruty, T., Maseda, A. (2010). Prevalence of functional disability in activities of daily living (ADL), instrumental activities of daily living (IADL) and associated factors, as predictors of morbidity and mortality. Archives of Gerontology and Geriatrics, 50, 306-310.

Mossakowska, M., Więcek, A., Błędowski, P. (2012). Aspekty medyczne, psychologiczne, socjologiczne $i$ ekonomiczne starzenia się ludzi w Polsce. Poznań: Termedia Wydawnictwo Medyczne.

Ramos-Pichardo, J. D., Cabrero-Garcia, J., Gonzalez-Llopis, L., Cabanero-Martınez, M. J., Munoz-Mendoza, C. L., Sanjuan-Quiles, A., Reig-Ferrer, A. (2014). What do older people understand by mobility-related difficulties? Archives of Gerontology and Geriatrics, 59, 122-130.

Roehrig, B., Hoeffken, K., Pientka, L.,Wedding, U. (2007). How many and which items of activities of daily living (ADL) and instrumental activities of daily living (IADL) are necessary for screening. Critical Reviews in Oncology/Hematology, 62, 164-171.

Robine, J. M., Jagger C. (2006). Health and Demography. Encyclopedia of Life Support Systems. Retrieved 15/08/2014, from http://www.eolss.net/Sample-Chapters/C04/E6-147-09.pdf.

Robine, J. M., Jagger, C., van Oyen H. (2006). Estimations of health expectancy at age 65 in European Union countries in 2004. France: Montpellier.

Sixsmith, J., Sixsmith, A., Malmgren Fänge, A., Naumann, D., Kucsera, C., Tomsone, S., Woolrych, R. (2014). Healthy ageing and home: The perspectives of very old people in five European countries. Social Science \& Medicine, 106, 1-9.

Sjolund, B. M., Wimo, A., Qiu, C., Engstrom, M., Strauss von, E. (2014). Time trends in prevalence of activities of daily living (ADL) disability and survival: Comparing two populations (aged 78+ years) living in a rural area in Sweden. Archives of Gerontology and Geriatrics, 58, 370-375.

Spector, W. D., Katz, S., Murphy, J. B., \& Fulton, J. P. (1987). The hierarchical relationship between activities of daily living and instrumental activities of daily living. Journal of Chronic Diseases, 6, 481-489.

Stineman, M. G., Streim, J. E., Pan, Q., Kurichi, J. E., Schüssler-Fiorenza Rose, S. M., Xie, D. (2014). Activity Limitation Stages Empirically Derived for Activities of Daily Living (ADL) and Instrumental ADL in the U.S. Adult Community-Dwelling Medicare Population. American Academy of Physical Medicine and Rehabilitation, 1 (in press).

Stjernborg, V., Melin Emilsson, U., Ståhl, A. (2014). Changes in outdoor mobility when becoming alone in the household in old age. Journal of Transport \& Health, 1, 9-16.

Ucieklak-Jeż, P. (2012). Porównanie czasu trwania życia w dobrym zdrowiu w Polsce. Opieka zdrowotna. Zagadnienia ekonomiczne. Warszawa: Difin.

Werngren-Elgstrom, M., Carlsson, G., Iwarsson, S. (2009). A 10-year follow-up study on subjective well-being and relationships to person-environment (P-E) fit and activity of daily living (ADL) dependence of older Swedish adults. Archives of Gerontology and Geriatrics, 49, 16-22.

Wilms, H. U., Riedel-Heller, S. G., \& Angermeyer, M. C. (2007). Limitations of activities of daily living and instrumental activities of daily living capacity in representative sample: Disentangling dementia and mobility related effects. Comprehensive Psychiatry, 1, 95-101.

WHO (2001). International Classification of Functioning, Disability and Health (ICF). Retrieved 15/08/2014, from http://www3.who.int/icf/intros/ICF-Eng-Intro.pdf.

WHO (2003). What are the main risk factors for disability in old age and how can disability be prevented? Retrieved 15/08/2014, from http://www.euro.who.int/document/E82970. 
Agnieszka BEM, Paulina UCIEKLAK-JEŻ. Functional Health Assessment as the Determinant of Social Care Management

Advised by Vincentas Lamanauskas, University of Šiauliai, Lithuania $\mid$\begin{tabular}{l|l} 
PROBLEMS \\
OF MANAGEMENT \\
IN THE 21.t CENTURY \\
vol. 9, No. 3, 2014
\end{tabular}

Received: November 12, 2014

Accepted: December 10, 2014

Agnieszka Bem Ph.D., Assistant Professor, Wroclaw University of Economics, Komandorska 118/120, 53-345 Wrockaw, Poland.

E-mail: agnieszka.bem@ue.wroc.pl

Website: http://www.ue.wroc.pl

Paulina Ucieklak-Jeż

Ph.D., Assistant Professor, Jan Dlugosz University in Czestochowa, Waszyngtona 4/8, 42-200 Czestochowa, Poland.

E-mail: p.ucieklak-jez@ajd.czest.pl 